\title{
Lactisole inhibits the glucose-sensing receptor T1R3 expressed in mouse pancreatic $\beta$-cells
}

\author{
Kunihisa Hamano',2, Yuko Nakagawa', Yoshiaki Ohtsu', Longfei Li', Johan Medina', \\ Yuji Tanaka², Katsuyoshi Masuda ${ }^{3}$, Mitsuhisa Komatsu ${ }^{4}$ and Itaru Kojima' \\ ${ }^{1}$ Institute for Molecular and Cellular Regulation, Gunma University, Maebashi 371-8512, Japan \\ ${ }^{2}$ Department of General Medicine, National Defense Medical College, Tokorozawa, Japan \\ ${ }^{3}$ Suntory Institute for Bioorganic Research, Osaka, Japan \\ ${ }^{4}$ Department of Internal Medicine, Shinshu University School of Medicine, Matsumoto, Japan
}

\author{
Correspondence \\ should be addressed \\ to I Kojima \\ Email \\ ikojima@gunma-u.ac.jp
}

\begin{abstract}
Glucose activates the glucose-sensing receptor T1R3 and facilitates its own metabolism in pancreatic $\beta$-cells. An inhibitor of this receptor would be helpful in elucidating the physiological function of the glucose-sensing receptor. The present study was conducted to examine whether or not lactisole can be used as an inhibitor of the glucose-sensing receptor. In MIN6 cells, in a dose-dependent manner, lactisole inhibited insulin secretion induced by sweeteners, acesulfame-K, sucralose and glycyrrhizin. The $\mathrm{IC}_{50}$ was $\sim 4 \mathrm{mmol} / \mathrm{l}$. Lactisole attenuated the elevation of cytoplasmic $\mathrm{Ca}^{2+}$ concentration $\left(\left[\mathrm{Ca}^{2+}\right]_{c}\right)$ evoked by sucralose and acesulfame-K but did not affect the elevation of intracellular cAMP concentration $\left([\mathrm{cAMP}]_{\mathrm{C}}\right)$ induced by these sweeteners. Lactisole also inhibited the action of glucose in MIN6 cells. Thus, lactisole significantly reduced elevations of intracellular [NADH] and intracellular [ATP] induced by glucose, and also inhibited glucose-induced insulin secretion. To further examine the effect of lactisole on T1R3, we prepared HEK293 cells stably expressing mouse T1R3. In these cells, sucralose elevated both $\left[\mathrm{Ca}^{2+}\right]_{c}$ and $[\mathrm{CAMP}]_{\mathrm{c}}$. Lactisole attenuated the sucralose-induced increase in $\left[\mathrm{Ca}^{2+}\right]_{\mathrm{c}}$ but did not affect the elevation of $[\mathrm{CAMP}]_{\mathrm{c}}$. Finally, lactisole inhibited insulin secretion induced by a high concentration of glucose in mouse islets. These results indicate that the mouse glucose-sensing receptor was inhibited by lactisole. Lactisole may be useful in assessing the role of the glucose-sensing receptor in mouse pancreatic $\beta$-cells.
\end{abstract}

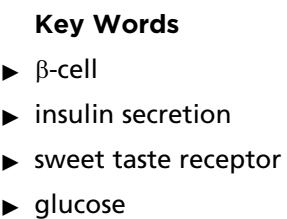

Key Words

- $\beta$-cell

- insulin secretion

- glucose

\section{Introduction}

Glucose is a primary stimulator of insulin secretion in pancreatic $\beta$-cells and modulates the effects of incretins and acetylcholine (Ashcroft \& Rorsman 1989, Rasmussen et al. 1990, Rorsman 1997, Newsholme et al. 2014). We have shown recently that T1R3, a subunit of the sweet taste receptor (Nelson et al. 2001, Temussi 2007), functions as a glucose-sensing receptor in $\beta$-cells (Malaisse 2014,
Nakagawa et al. 2014, Kojima et al. 2015). This receptor is activated by glucose, and promotes metabolism of fuels in $\beta$-cells leading to an increase in ATP (Nakagawa et al. 2014). Since knockdown of T1R3 attenuates glucose-induced elevation of intracellular ATP $\left([\mathrm{ATP}]_{\mathrm{c}}\right.$ ), the glucose-sensing receptor T1R3 is involved in the action of glucose (Kojima et al. 2015). At present, the 
physiological role of this receptor in $\beta$-cells is not completely elucidated. A specific and useful inhibitor of T1R3 would be helpful in assessing the physiological functions of the glucose-sensing receptor in $\beta$-cells.

T1R3 belongs to the class C G protein-coupled receptor and forms a heterodimer with T1R2 or T1R1. The T1R2/T1R3 heterodimer functions as the sweet taste receptor while T1R3/T1R1 functions as the umami receptor (Nelson et al. 2001, Roper 2007, 2013, Temussi 2007). T1R3 is a key molecule in sweet taste perception and many activators and inhibitors were identified (Temussi 2007). Among these inhibitors, lactisole, which is 2-(4-methoxyphenol) propionic acid, inhibits perception of sweet taste by acting on T1R3 (Johnson et al. 1994, Sclafani \& Perez 1997, Xu et al. 2004). Jiang et al. (2005) showed that lactisole acts on the transmembrane domain (TMD) of T1R3. They further narrowed down the specific region in TMD that interacts with lactisole and identified critical residues in the TMD of T1R3 (Jiang et al. 2005).

Subunits of the sweet taste receptor are also expressed in extragustatory organs including enteroendocrine cells (Bezencon et al. 2007, Margolskee et al. 2007, Jang et al. 2010), pancreatic $\beta$-cells (Nakagawa et al. 2009, Geraedts et al. 2012, Kyriazis et al. 2012) and adipocytes (Masubuchi et al. 2013). Unlike taste cells of the tongue, the expression level of T1R2 is much lower compared to that of T1R3 in these cells (Masubuchi et al. 2013, Nakagawa et al. 2013, Medina et al. 2014, Ohtsu et al. 2014), and a homodimer of T1R3 may function as the sweet taste-sensing receptor (Masubuchi et al. 2013, Nakagawa et al. 2013, Medina et al. 2014, Ohtsu et al. 2014). Specifically in $\beta$-cells, the expression of T1R2 is far less than that of T1R3 (Medina et al. 2014). Furthermore, knockdown of T1R3 attenuated the effects of sweeteners whereas knockdown of T1R2 was ineffective (Nakagawa et al. 2013). It is quite likely that a major component of the sweet taste-sensing receptor in $\beta$-cells may be a homodimer of T1R3 (Nakagawa et al. 2013, Kojima et al. 2015). The physiological function and its role in the regulation of insulin secretion are largely unknown. In this regard, the inhibitor of the glucosesensing receptor, if any, is useful to assess the role of the receptor in the regulation of insulin secretion.

To block the glucose-sensing receptor in $\beta$-cells, the putative compound should inhibit the homodimer of T1R3. Among various inhibitors of sweet taste perception, lactisole is the most interesting candidate since it acts on the specific region of T1R3 (Xu et al. 2004, Jiang et al. 2005). Unfortunately, it was reported that the effect of lactisole was dependent on species. Thus, it inhibits sweet taste sensation in humans (Johnson et al. 1994) whereas it is ineffective in rodents (Johnson et al. 1994, Jiang et al. 2005). These reports negate the function of lactisole as an inhibitor of the glucose-sensing receptor in rodents. In this regard, Oya et al. (2011) reported recently that lactisole inhibits the umami receptor function in MIN6 cells. Their results suggest that mouse T1R3 (mT1R3) is not totally insensitive to lactisole. Nevertheless, since their results are apparently contradictory to previous reports (Johnson et al. 1994, Jiang et al. 2005), investigators in the field of taste research cast some doubts on their results. This is an important issue since, if it is true, lactisole can be used as an inhibitor of the glucose-sensing receptor in humans and rodents. Given that properties of the glucose-sensing receptor in $\beta$-cells may be slightly different from those of the canonical sweet taste receptor in the taste buds, it is indeed worth testing whether the glucose-sensing receptor expressed in mouse $\beta$-cells is inhibited by lactisole. In the present study, we examined this possibility. The results clearly show that lactisole inhibits the mouse glucose-sensing receptor mT1R3. Lactisole may provide a useful pharmacological tool to assess the function of the glucose-sensing receptor in pancreatic $\beta$-cells.

\section{Materials and methods}

\section{Materials}

Lactisole and sucralose were obtained from SigmaAldrich. Acesulfame-K and glycyrrhizin were from Wako Pure Chemical Industry (Osaka, Japan). These chemicals were dissolved in Hank's balanced salt solution (HBSS) containing $138 \mathrm{mmol} / \mathrm{l} \mathrm{NaCl}, 5.4 \mathrm{mmol} / \mathrm{l} \mathrm{KCl}, 1.3 \mathrm{mmol} / 1$ $\mathrm{CaCl}_{2}, \quad 0.44 \mathrm{mmol} / 1 \quad \mathrm{KH}_{2} \mathrm{PO}_{4}, \quad 0.5 \mathrm{mmol} / \mathrm{l} \quad \mathrm{MgCl}_{2}$, $0.38 \mathrm{mmol} / \mathrm{l} \mathrm{MgSO}_{4}, 0.34 \mathrm{mmol} / \mathrm{l} \mathrm{Na} \mathrm{HPO}_{4}, 5.5 \mathrm{mmol} / \mathrm{l}$ D-glucose and $10 \mathrm{mmol} / \mathrm{l} \mathrm{HEPES} / \mathrm{NaOH}(\mathrm{pH}$ 7.4). To prepare lactisole-containing buffer, we dissolved the compound in HBSS or Krebs-Ringer-HEPES (KRH) buffer and $\mathrm{pH}$ was adjusted to 7.4 by adding $\mathrm{NaOH}$.

\section{Cell culture}

MIN6 cells (Miyazaki et al. 1990) were grown in DMEM containing a high concentration of glucose (Invitrogen) and $10 \%$ fetal bovine serum (FBS) (Sigma-Aldrich) and cultured in a humidified incubator with 95\% air and 5\% $\mathrm{CO}_{2}$ at $37^{\circ} \mathrm{C}$. HEK293 cells were cultured in DMEM containing 10\% FBS.

Published by Bioscientifica Ltd 


\section{Measurement of insulin secretion}

MIN6 cells were cultured in a 24-well plate and incubated for $48 \mathrm{~h}$. Cells were then incubated for $1 \mathrm{~h}$ in KRH buffer containing $136 \mathrm{mmol} / 1 \mathrm{NaCl}, 4.8 \mathrm{mmol} / 1 \mathrm{KCl}, 1.3 \mathrm{mmol} / 1$ $\mathrm{CaCl}_{2}, \quad 1.2 \mathrm{mmol} / \mathrm{l} \quad \mathrm{MgSO}_{4}, \quad 1.2 \mathrm{mmol} / \mathrm{l} \quad \mathrm{KH}_{2} \mathrm{PO}_{4}$, $5.0 \mathrm{mmol} / 1 \mathrm{NaHCO}, 10 \mathrm{mmol} / \mathrm{l} \mathrm{HEPES} / \mathrm{NaOH}(\mathrm{pH} 7.4)$ and $0.1 \%$ BSA. Cells were then incubated for $1 \mathrm{~h}$ in the same buffer containing $5.5 \mathrm{mmol} / \mathrm{l}$ glucose in the presence and absence of various agents. The supernatant was collected and centrifuged at $300 \boldsymbol{g}$ for $10 \mathrm{~min}$ to remove cell debris. The insulin concentration in the supernatant was measured by RIA (Eiken Chemical, Tokyo, Japan) according to the manufacturer's protocol (Nakagawa et al. 2009). Insulin content was measured as described previously (Nakagawa et al. 2009) and secreted insulin was expressed as a percent of the insulin content. Statistical analysis was performed by using Student's $t$-test.

C57BL/6J (B6) and T1R3-null mice were obtained from the Jackson Laboratory (Bar Harbor, ME, USA). Mouse pancreatic islets were isolated by using collagenase (Gotoh et al. 1985). Isolated islets were preincubated for $1 \mathrm{~h}$ in $\mathrm{KRH}$ buffer. Then the islets were incubated for $1 \mathrm{~h}$ in KRH buffer containing $5.5 \mathrm{mmol} / \mathrm{l}$ glucose and various compounds unless otherwise mentioned. The supernatant was collected and insulin concentration was measured by RIA (Nakagawa et al. 2009). Secreted insulin was expressed as a percent of the insulin content.

\section{Measurement of cytoplasmic $\mathrm{Ca}^{2+}$ concentration and NADH in MIN6 cells}

HBSS was used for measurement of cytoplasmic $\mathrm{Ca}^{2+}$ concentration $\left(\left[\mathrm{Ca}^{2+}\right]_{c}\right)$ and intracellular NADH concentration [NADH].

$\left[\mathrm{Ca}^{2+}\right]_{\mathrm{c}}$ was monitored by using a fluorescent $\mathrm{Ca}^{2+}$ indicator fluo-8. MIN6 cells were loaded with fluo-8 by incubating in HBSS containing $4 \mu \mathrm{mol} / \mathrm{l}$ fluo-8/AM for $20 \mathrm{~min}$ at room temperature. Cells were placed on a $35 \mathrm{~mm}$ glass bottom culture dish. Before the measurement, cells were incubated in HBSS and were visualized with a 40 UApo/340 objective lens (Olympus). To detect the fluorescence images, we used the AQUACOSMOS/ ASHURA imaging system (Hamamatsu Photonics, Hamamatsu, Japan; Nakagawa et al. 2009). The values $(F)$ were normalized to each initial value $\left(F_{0}\right)$ and the relative fluorescence change was referred to as $F / F_{0}$ (Nakagawa et al. 2009). [NADH] was monitored by measuring autofluorescence using a $380 \mathrm{~nm}$ emission filter. In each experiment, recordings were obtained in more than ten cells.
Results are expressed as mean \pm s.E.M. of accumulated data obtained in multiple experiments. For determination of dose-response relationship and analyses of the effects of inhibitors, the area under the curve (AUC) was calculated. Statistical analysis was performed using Student's $t$-test.

\section{Measurement of cytoplasmic CAMP concentration in MIN6 cells}

Changes in cytoplasmic cAMP concentration $\left([\mathrm{cAMP}]_{\mathrm{c}}\right)$ were monitored by using Epac1-camps (Nikolaev et al. 2004) kindly provided by Dr Martin Lohse (University of Würzburg, Germany). MIN6 cells were transiently transfected with $5.4 \mu \mathrm{g}$ of plasmid encoding Epac1-camps using Lipofectamine 2000 transfection reagent (Invitrogen; Nakagawa et al. 2009). Transfected cells were incubated in HBSS. For imaging, cells were visualized with a 40 UApo/340 objective lens (Olympus). The Epac1-camps excitation wavelength was $440 \mathrm{~nm}$ and attenuated by $6 \%$ using neutral density filters. For dual emission ratio imaging for enhanced cyan fluorescent protein and enhanced yellow fluorescent protein, we used AQUACOSMOS/ASHURA, a 3CCD based fluorescence energy transfer imaging system (Hamamatsu Photonics).

\section{Measurement of cytoplasmic ATP in MIN6 cells}

MIN6 cells expressing luciferase (Nakagawa et al. 2014) were seeded into a culture plate-96 and incubated for 2-3 days before the measurement of ATP. Cells were then incubated for $20 \mathrm{~min}$ in HBSS containing $50 \mu \mathrm{mol} / \mathrm{l}$ D-luciferin potassium salt (Wako Pure Chemical Industry) in a $37^{\circ} \mathrm{C}$ incubator. To measure the basal ATP concentration $\left(L_{\mathrm{O}}\right)$, we counted the emitted photons with an EnSpire (Perkin Elmer, Waltham, MA, USA) for $20 \mathrm{~min}$. The cells were then incubated in the presence or absence of stimulatory agents. We counted the emitted photon for $1 \mathrm{~h}$. These values $(L)$ were normalized to each basal value $\left(L_{\mathrm{o}}\right)$ so that the relative luminescence changes were referred to as $L / L_{\mathrm{o}}$ (Nakagawa et al. 2014).

\section{Establishment of HEK293 cell lines expressing mT1R3}

HEK293 cells cultured in a $100 \mathrm{~mm}$ culture dish were dispersed with PBS containing 0.05\% trypsin-EDTA (Life Technologies). After washing with growth medium, cells were resuspended in Electroporation Buffer (Bio-Rad). Then $0.55 \mathrm{ml}$ of cell aliquot was mixed with $0.2 \mathrm{ml}$ of mT1R3 pcDNA3.1 + neo (a gift from Yutaka Maruyama, Ajinomoto Co., Inc., Kawasaki, Japan; $30 \mu \mathrm{g}$ ) in a $0.4 \mathrm{~cm}$-gap cuvette

Published by Bioscientifica Ltd 
before a single pulse of electroporation was administered using Gene Pulser Xcell (Bio-Rad) set at voltage $200 \mathrm{~V}$ and time constant $28 \mathrm{~ms}$. Cells were selected for antibiotic resistance to G-418 sulfate ( $1 \mathrm{~g} / \mathrm{l}$, Wako Pure Chemical Industry) for 10 days. One hundred and twenty resistant colonies were expanded, and their $\mathrm{Ca}^{2+}$ responses to the sweet taste receptor agonist were evaluated by using fluorescence microscopy. Six responding colonies were isolated, and the strongest responding cell line was used for all analyses.

\section{Results}

We first examined the effect of various concentrations of lactisole on insulin secretion induced by T1R3 agonists in MIN6 cells. In these cells, an artificial sweetener sucralose, which activates the glucose-sensing receptor T1R3 (Nakagawa et al. 2009, 2013, 2014), induced an approximately threefold increase in insulin secretion in the presence of $5.5 \mathrm{mmol} / \mathrm{l}$ glucose. This increase in insulin secretion induced by sucralose was inhibited by an addition of lactisole (Fig. 1A). In the presence of $3 \mathrm{mmol} / \mathrm{l}$ lactisole, sucralose-induced secretion was $\sim 60 \%$. At $10 \mathrm{mmol} / \mathrm{l}$, lactisole nearly completely blocked the effect of sucralose. The $\mathrm{IC}_{50}$ of the effect of lactisole was $\sim 4.0 \mathrm{mmol} / \mathrm{l}$. Similarly, acesulfame-K induced a fourfold increase in insulin secretion and lactisole inhibited acesulfame-K-induced insulin secretion in a dose-dependent manner (Fig. 1B). In addition, insulin secretion induced by glycyrrhizin was inhibited by lactisole (Fig. 1C). In sharp contrast, lactisole did not affect insulin secretion induced by a depolarizing concentration of $\mathrm{KCl}$ (Fig. 1D). Lactisole did not affect the viability of the cells as assessed by using Trypan blue (data not shown). Kyriazis et al. (2014) recently reported that lactisole increased basal insulin secretin in human $\beta$-cells. We examined the effect of lactisole on basal secretin in MIN6 cells. As shown in Fig. 1E, lactisole did not affect the basal secretion.

We then examined the effect of lactisole on sucraloseinduced elevation of $\left[\mathrm{Ca}^{2+}\right]_{\mathrm{c}}$. As shown in Fig. 2A, sucralose induced an immediate increase in $\left[\mathrm{Ca}^{2+}\right]_{\mathrm{c}}$, which was followed by sustained elevation of $\left[\mathrm{Ca}^{2+}\right]_{\mathrm{c}}$. The effect of sucralose was markedly inhibited by $5 \mathrm{mmol} / \mathrm{l}$ lactisole. Figure $2 \mathrm{~B}$ depicts the effect of lactisole on sucralose-induced elevation of $\left[\mathrm{Ca}^{2+}\right]_{\mathrm{c}}$ assessed by measuring AUC. Likewise, elevation of $\left[\mathrm{Ca}^{2+}\right]_{c}$ induced by acesulfame-K was significantly inhibited by lactisole (Fig. 2C and D). In contrast, lactisole did not affect elevation of $\left[\mathrm{Ca}^{2+}\right]_{\mathrm{c}}$ induced by a high concentration of potassium (Fig. 2E and F). In addition to $\left[\mathrm{Ca}^{2+}\right]_{\mathrm{c}}$, sucralose also induced elevation of $[\mathrm{cAMP}]_{\mathrm{c}}$ (Fig. 3A). In sharp contrast to the effects on $\left[\mathrm{Ca}^{2+}\right]_{\mathrm{c}}$, lactisole did not affect sucralose-induced elevation of $[\mathrm{CAMP}]_{\mathrm{c}}$ (Fig. 3A and B). Similarly, lactisole did not affect the elevation of [cAMP $]_{\mathrm{C}}$ induced by acesulfame-K (Fig. 3C and D).

The preceding results suggest that lactisole inhibits $\left[\mathrm{Ca}^{2+}\right]_{\mathrm{c}}$ response mediated by mT1R3. To further confirm this, we permanently expressed mT1R3 in HEK293 cells and examined the effect of lactisole. In naïve HEK293 cells or mock-transfected HEK293 cells, sucralose did not cause any change in $\left[\mathrm{Ca}^{2+}\right]_{\mathrm{c}}$ (data not shown). In HEK293 cells expressing $\mathrm{mT1R} 3$, sucralose induced a transient elevation of $\left[\mathrm{Ca}^{2+}\right]_{\mathrm{c}}$ (Fig. $4 \mathrm{~A}$ ). It is of note that $\left[\mathrm{Ca}^{2+}\right]_{\mathrm{c}}$ response to sucralose was obtained by transfection of mT1R3 alone and transfection of gustducin or a chimeric $G$ protein (Nelson et al. 2001) was not required. Elevation of $\left[\mathrm{Ca}^{2+}\right]_{\mathrm{c}}$ induced by sucralose was markedly inhibited by lactisole (Fig. 4B). In contrast, lactisole did not affect elevation of $[\mathrm{CAMP}]_{\mathrm{c}}$ induced by sucralose (Fig. 4B and C). Likewise, acesulfame-K induced biphasic increase in $\left[\mathrm{Ca}^{2+}\right]_{\mathrm{c}}$, which was inhibited by lactisole (Fig. 4E and F).

We reported previously that activation of the glucosesensing receptor led to an increase in $[\mathrm{ATP}]_{\mathrm{C}}$ by facilitating
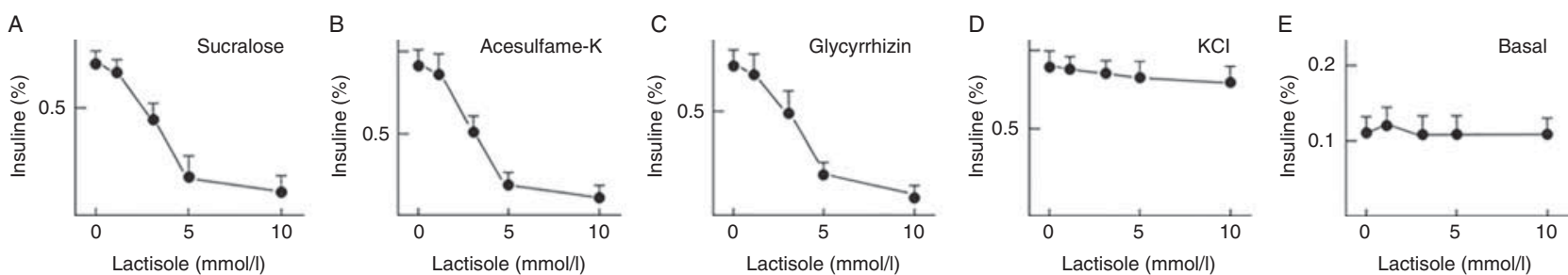

\section{Figure 1}

Effect of lactisole on insulin secretion in MIN6 cells. MIN6 cells were incubated with $40 \mathrm{mmol} / \mathrm{l}$ sucralose (A), $40 \mathrm{mmol} / \mathrm{l}$ acesulfame-K (B), $3 \mathrm{mmol} / \mathrm{l}$ glycyrrhizin (C) and $40 \mathrm{mmol} / \mathrm{l} \mathrm{KCl}(\mathrm{D})$ in the presence and absence of various concentrations of lactisole, and insulin in the medium was measured. Effects of lactisole in the absence of stimulator were also examined $(E)$. Values are the mean \pm S.E.M. for four experiments. http://joe.endocrinology-journals.org DOI: $10.1530 / J O E-15-0102$ (c) 2015 The authors Printed in Great Britain
Published by Bioscientifica Ltd 

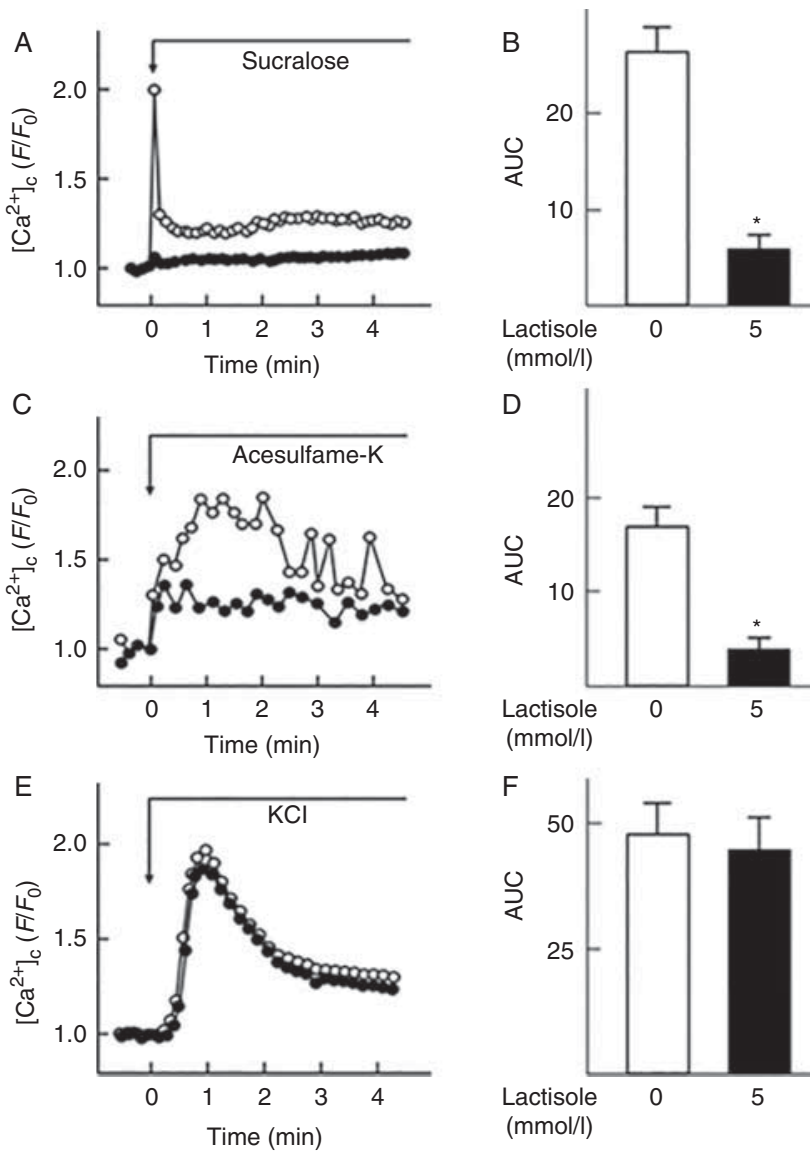

Figure 2

Effect of lactisole on elevation of $\left[\mathrm{Ca}^{2+}\right]_{c}$ induced by sucralose and acesulfame-K in MIN6 cells. (A) MIN6 cells were stimulated by $40 \mathrm{mmol} / \mathrm{l}$ sucralose in the presence (filled circle) and absence (open circle) of $5 \mathrm{mmol} / \mathrm{l}$ lactisole and changes in $\left[\mathrm{Ca}^{2+}\right]_{c}$ were monitored. Values are the mean of ten determinations. Note that $40 \mathrm{mmol} / \mathrm{l}$ mannitol did not affect $\left[\mathrm{Ca}^{2+}\right]_{\mathrm{C}}$. (B) Cells were stimulated as shown in A and quantitative analysis was done by measuring AUC. Values are the mean \pm s.E.M. for three experiments. $* P<0.01$ vs without lactisole. (C) MIN6 cells were stimulated with $30 \mathrm{mmol} / \mathrm{l}$ acesulfame-K in the presence (filled circle) and absence (open circle) of $5 \mathrm{mmol} / \mathrm{l}$ lactisole and changes in $\left[\mathrm{Ca}^{2+}\right]_{\mathrm{c}}$ were monitored. Values are the mean of ten determinations. (D) Cells were stimulated as shown in $C$ and AUC was calculated. Values are the mean \pm s.E.M. for three experiments. $* P<0.01$ vs without lactisole. (E) MIN6 cells were stimulated by $40 \mathrm{mmol} / \mathrm{l}$ $\mathrm{KCl}$ in the presence (filled circle) and absence (open circle) of $5 \mathrm{mmol} / \mathrm{l}$ lactisole. Values are the mean of responses of 20 determinations. (F) Experiments were performed as shown in E and AUC was calculated. Values are the mean \pm s.E.M. for 20 determinations.

glucose metabolism (Nakagawa et al. 2014). Accordingly, artificial sweeteners increase $[\mathrm{ATP}]_{\mathrm{c}}$ even though they do not serve as substrates for glycolysis. We next examined the effect of lactisole on elevation of $[\mathrm{NADH}]$ and $[\mathrm{ATP}]_{\mathrm{c}}$ induced by a sweetener sucralose. As shown in Fig. 5A, sucralose increased [NADH] in MIN6 cells. Lactisole inhibited the effect of sucralose on [NADH] (Fig. 5A and B).
Likewise, addition of sucralose induced an immediate increase in $[\mathrm{ATP}]_{\mathrm{C}}$, which was markedly inhibited by lactisole (Fig. 5C and D).

We next examined whether lactisole modulates the effect of glucose in MIN6 cells. As shown in Fig. 6A, $25 \mathrm{mmol} / \mathrm{l}$ glucose induced an increase in [NADH]. Glucose-induced elevation of [NADH] was significantly reduced by lactisole (Fig. $6 \mathrm{~A}$ and B). High concentration of glucose also evoked a biphasic increase in $[\mathrm{ATP}]_{\mathrm{C}}$ (Fig. 6C). Lactisole markedly reduced the elevation of $[\mathrm{ATP}]_{\mathrm{C}}$ induced by glucose (Fig. 6C and D). It is well known that glucose elevates $[\mathrm{ATP}]_{\mathrm{c}}$ and thereby inhibits the ATP-sensitive potassium $\left(\mathrm{K}_{\mathrm{ATP}}\right)$ channel (Ashcroft \& Rorsman 1989, Rorsman 1997). Resultant depolarization of the plasma membrane induces $\mathrm{Ca}^{2+}$ entry via the voltage-dependent $\mathrm{Ca}^{2+}$ channel (Ashcroft \& Rorsman 1989, Rorsman 1997). As shown in Fig. 6E, $25 \mathrm{mmol} / \mathrm{l}$ glucose induced elevation of $\left[\mathrm{Ca}^{2+}\right]_{\mathrm{c}}$ after a certain lag period. The glucose-induced elevation of $\left[\mathrm{Ca}^{2+}\right]_{\mathrm{c}}$ was delayed and significantly blunted by the addition of lactisole (Fig. $6 \mathrm{E}$ and F). In agreement

A
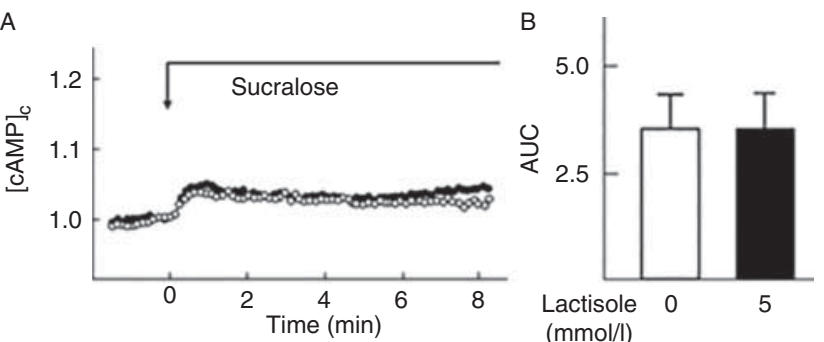

C

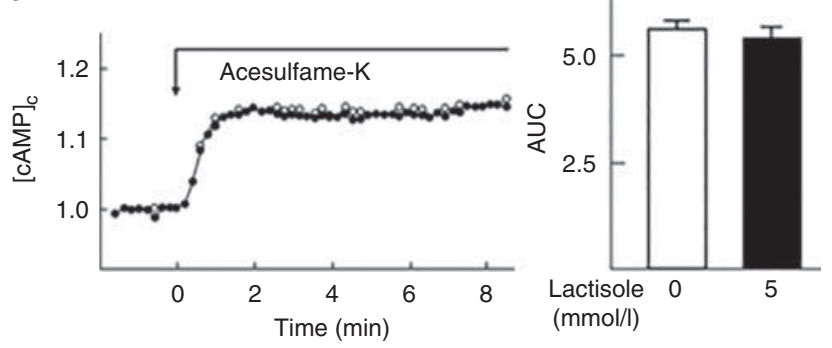

Figure 3

Effect of lactisole on elevation of [cAMP $]_{c}$ in MIN6 cells. (A) Epac1-campsexpressing MIN6 cells were stimulated by $40 \mathrm{mmol} / \mathrm{l}$ sucralose in the presence (filled circle) and absence (open circle) of $5 \mathrm{mmol} / \mathrm{l}$ lactisole. Changes in $[\mathrm{CAMP}]_{C}$ was monitored. Values are the mean of ten determinations. (B) Experiments were performed as mentioned in A and AUC was calculated. Values are the mean \pm s.E.M. for ten determinations and representative of two experiments. (C) Cells were stimulated by $40 \mathrm{mmol} / \mathrm{l}$ acesulfame-K in the presence (filled circle) and absence (open circle) of $5 \mathrm{mmol} / \mathrm{l}$ lactisole. Values are the mean of ten determinations. (D) Experiments were performed as in C and AUC was calculated. Values are the mean \pm S.E.M. of ten determinations and the representative of two experiments.

Published by Bioscientifica Ltd 
A

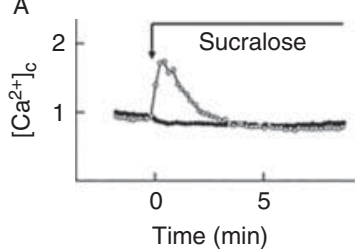

B
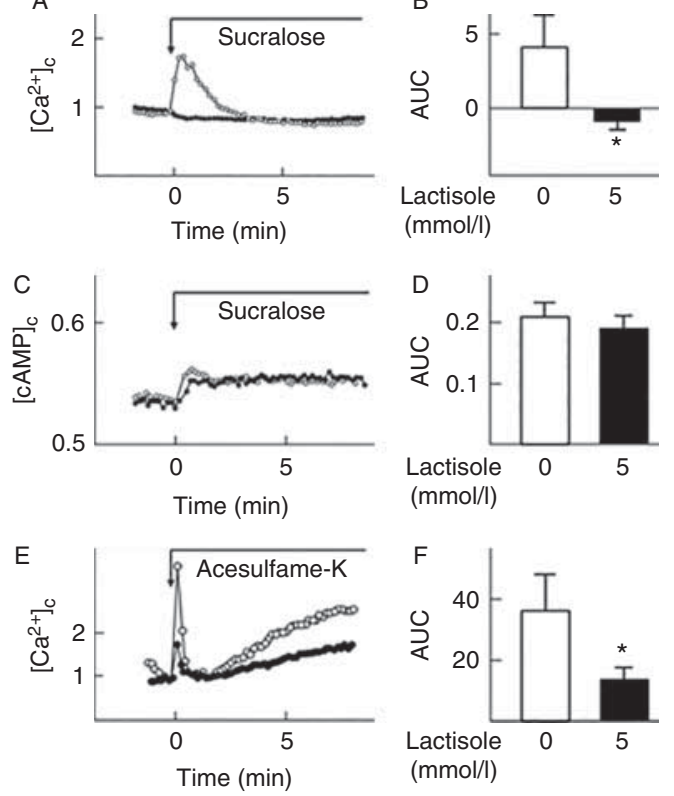
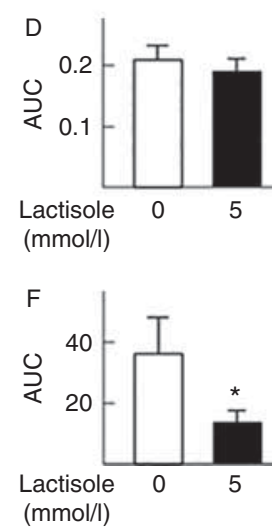

Figure 4

Effect of lactisole on $\left[\mathrm{Ca}^{2+}\right]_{C}$ and $[\mathrm{CAMP}]_{C}$ in HEK293 cells stably expressing mT1R3. (A) HEK293 cells expressing mT1R3 were stimulated by $40 \mathrm{mmol} / \mathrm{l}$ sucralose in the presence (filled circle) and absence (open circle) of $5 \mathrm{mmol} / \mathrm{l}$ lactisole and changes in $\left[\mathrm{Ca}^{2+}\right]_{\mathrm{c}}$ were monitored. Values are the mean of ten determinations. (B) Experiments were done as in A and AUC was calculated. Values are the mean \pm s.E.M. for three experiments. ${ }^{*} P<0.01$ vs without lactisole. (C) HEK293 cells stably expressing mT1R3 were stimulated by $40 \mathrm{mmol} / \mathrm{l}$ sucralose in the presence (filled circle) and absence (open circle) of $5 \mathrm{mmol} / \mathrm{l}$ lactisole and changes in [CAMP $]_{C}$ were monitored. Values are the mean of ten determinations. (D) Experiments were performed as in $\mathrm{C}$ and AUC was calculated. Values are the mean \pm s.E.M. for ten determinations and representative of two experiments. (E) HEK293 cells stably expressing $\mathrm{mT} 1 \mathrm{R} 3$ were stimulated by $40 \mathrm{mmol} / \mathrm{l}$ acesulfame- $\mathrm{K}$ in the presence (filled circle) and absence (open circle) of $5 \mathrm{mmol} / \mathrm{l}$ lactisole, and changes in $\left[\mathrm{Ca}^{2+}\right]_{C}$ were monitored. Values are the mean of ten determinations. (F) Experiments were performed as in $E$ and AUC was calculated. Values are the mean \pm s.E.M. for ten determinations. $* P<0.05$ vs without lactisole.

with this observation, lactisole significantly reduced insulin secretion induced by glucose (Fig. 7A). It is known that glucose action in $\beta$-cells is exerted through two different pathways: a triggering pathway or $\mathrm{K}_{\mathrm{ATP}}$ channel-dependent pathway, and an amplifying pathway or $\mathrm{K}_{\mathrm{ATP}}$ channel-independent pathway (Gembal et al. 1992, Sato et al. 1992, Henquin 2009). It was reported that the $\mathrm{K}_{\mathrm{ATP}}$ channel independent pathway was inhibited by an inhibitor of glucose recognition site in the plasma membrane (Aizawa et al. 1994). To confirm this, we examined whether or not lactisole inhibits insulin secretion induced by glucose in the presence of diazoxide and depolarizing concentration of $\mathrm{KCl}$. As shown in Fig. 7B, lactisole significantly reduced insulin secretion in

the presence of glucose, diazoxide and high concentration of $\mathrm{KCl}$.

Finally, we examined the effect of lactisole in mouse pancreatic islets. Lactisole did not alter the basal secretion of insulin (Fig. 8A). Glucose induced an approximately fivefold increase in insulin secretion in mouse islets. Lactisole attenuated insulin secretion induced by glucose (Fig. 8A). In contrast, lactisole did not affect insulin secretion induced by a depolarizing concentration of potassium (Fig. 8B). We also examined the effect of lactisole in islets obtained from T1R3 knockout mice. As shown in Fig. 8C, insulin secretion induced by glucose was reduced in T1R3-null islets. In these islets, lactisole did not affect glucose-induced insulin secretion.

\section{Discussion}

Results obtained in the present study demonstrated that lactisole inhibited insulin secretion induced by sweeteners
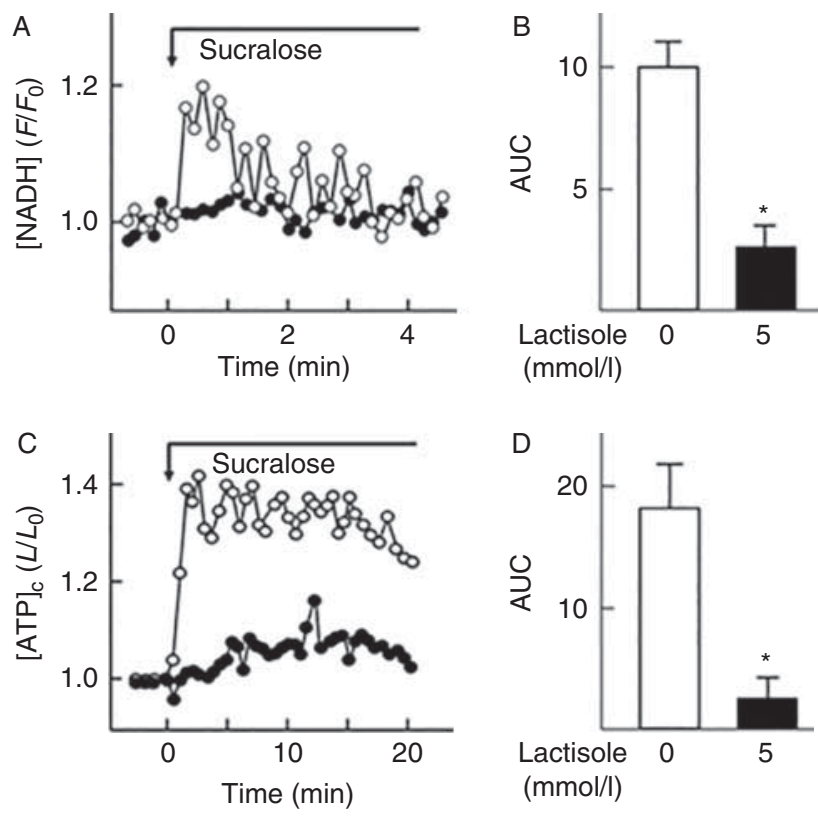

\section{Figure 5}

Effect of lactisole on changes in [NADH] and [ATP $]_{C}$ in MIN6 cells. (A) MIN6 cells were stimulated by $10 \mathrm{mmol} / \mathrm{l}$ sucralose in the presence (filled circle) and absence (open circle) of $5 \mathrm{mmol} / \mathrm{l}$ lactisole and changes in [NADH] were monitored. Values are the mean \pm s.E.M. for ten determinations. Note that the glucose concentration in medium was $5.5 \mathrm{mmol} / \mathrm{l}$. (B) Experiments were performed as shown in A and AUC was calculated. Values are the mean \pm S.E.M. for four experiments. ${ }^{*} P<0.05$ vs without lactisole. (C) MIN6 cells were stimulated by $10 \mathrm{mmol} / \mathrm{l}$ sucralose in the presence (filled circle) and absence (open circle) of $5 \mathrm{mmol} / /$ lactisole and changes in $[A T P]_{C}$ were monitored. Values are the mean of four experiments. (D) Experiments were performed as shown in $C$ and AUC was calculated. Values are the mean \pm S.E.M. for four experiments. ${ }^{\star} P<0.05$ vs without lactisole. 

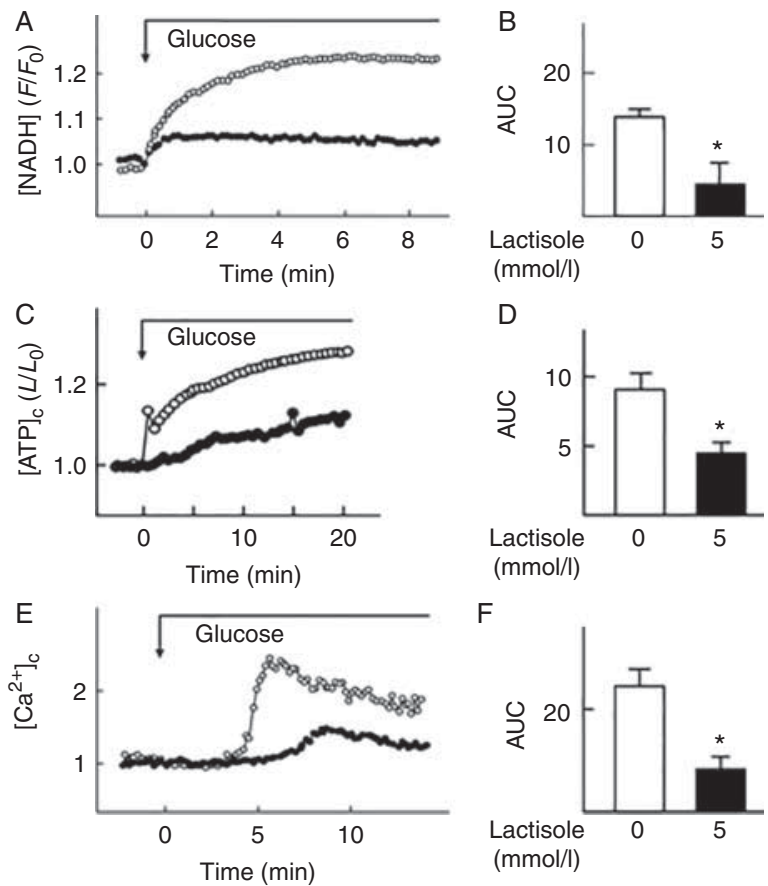

D

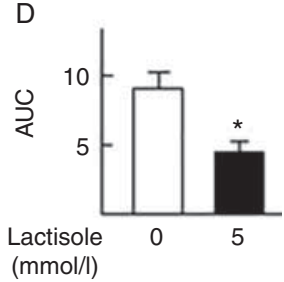

$\mathrm{F}$

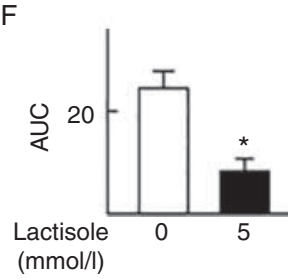

Figure 6

Effects of lactisole on the effects of glucose. (A) MIN6 cells were stimulated by $25 \mathrm{mmol} / \mathrm{l}$ glucose in the presence (filled circle) and absence (open circle) of $5 \mathrm{mmol} / \mathrm{l}$ lactisole and changes in [NADH] were monitored. Values are the mean of responses of ten determinations. (B) Experiments were carried out as shown in A and AUC was calculated. Values are the mean \pm s.E.M. for ten determinations and representative of three experiments. ${ }^{*} P<0.01$ vs without lactisole. (C) MIN6 cells were stimulated by $25 \mathrm{mmol} / \mathrm{l}$ glucose in the presence (filled circle) and absence (open circle) of $5 \mathrm{mmol} / \mathrm{l}$ lactisole and changes in $[A T P]_{C}$ were monitored. Values are the mean of four experiments. (D) Experiments are carried out as shown in $\mathrm{C}$ and AUC was calculated. Values are the mean \pm S.E.M. for four experiments. ${ }^{*} P<0.01$ vs without lactisole. (E) MIN6 cells were stimulated with $25 \mathrm{mmol} / \mathrm{l}$ glucose in the presence (filled circle) and absence (open circle) of $5 \mathrm{mmol} / \mathrm{l}$ lactisole and changes in $\left[\mathrm{Ca}^{2+}\right]_{c}$ were monitored. Values are the mean of ten determinations. Note that glucose concentration in medium before stimulation was $5.5 \mathrm{mmol} / \mathrm{l}$. (F) Experiments were carried out as shown in $E$ and AUC was calculated. Values are the mean \pm s.E.M. for ten determinations and representative of two experiments. ${ }^{*} P<0.01$ vs without lactisole.

in dose-dependent manners (Fig. 1). The $\mathrm{IC}_{50}$ was $\sim 4 \mathrm{mmol} / \mathrm{l}$. In contrast, lactisole had no effect on insulin secretion induced by the depolarizing concentration of $\mathrm{KCl}$. Likewise, lactisole inhibited $\left[\mathrm{Ca}^{2+}\right]_{\mathrm{c}}$ response to sweeteners without affecting the $\left[\mathrm{Ca}^{2+}\right]_{c}$ response to $\mathrm{KCl}$. Furthermore, lactisole blocked the increase in $[\mathrm{ATP}]_{\mathrm{c}}$ induced by the sweetener. These results clearly show that the glucose-sensing receptor in mouse $\beta$-cells is inhibited by lactisole. Further support came from the experiments performed in HEK293 cells. In HEK293 cells stably expressing mT1R3, sucralose evoked an elevation of $\left[\mathrm{Ca}^{2+}\right]_{\mathrm{c}}$, which was inhibited by lactisole. It should be noted that doses of lactisole that inhibited mT1R3 were slightly higher than that which inhibited human T1R3 (hT1R3; Johnson et al. 1994, Xu et al. 2004, Jiang et al. 2005). Thus, hT1R3 was blocked by $1 \mathrm{mmol} / 1$ lactisole (Jiang et al. 2005) whereas $1 \mathrm{mmol} / \mathrm{l}$ lactisole showed only a small inhibitory effect on mT1R3 (Fig. 1). mT1R3 was less sensitive to lactisole as compared to hT1R3. In any event, lactisole was able to inhibit mT1R3, although slightly higher concentrations were needed. This notion is apparently different from what has been widely thought (Johnson et al. 1994, Sclafani \& Perez 1997, Xu et al. 2004). In this regard, Jiang et al. (2005) used a fixed dose of lactisole, i.e. $1 \mathrm{mmol} / \mathrm{l}$, and showed that mT1R3 was resistant to lactisole. In fact, they prepared series of chimeric receptors replacing hT1R3 sequences with the mouse ones, and identified a region responsible for inhibition by lactisole. However, even their insensitive chimeras were inhibited when higher concentrations of lactisole were administered (Jiang et al. 2005). Taken
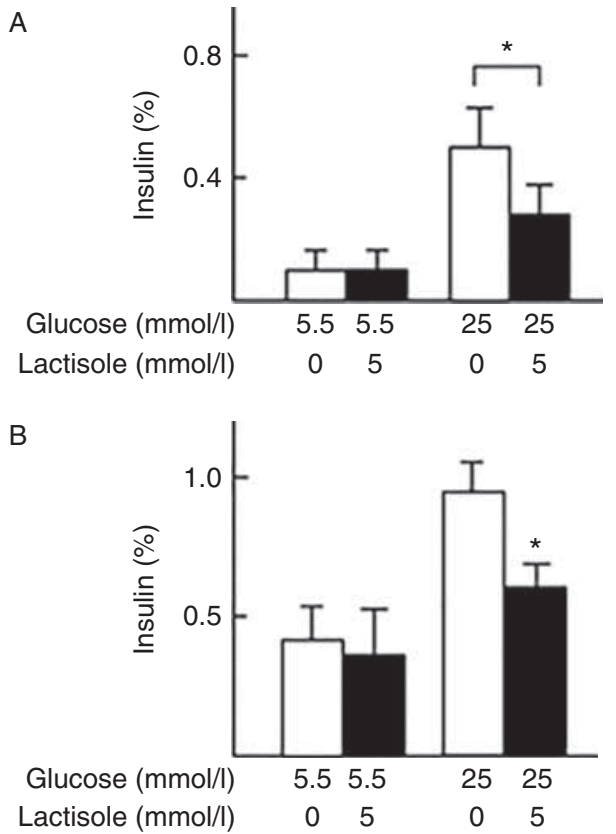

\section{Figure 7}

Effect of lactisole on insulin secretion in MIN6 cells. (A) MIN6 cells were incubated for $60 \mathrm{~min}$ with either 5.5 or $25 \mathrm{mmol} / \mathrm{l}$ glucose in the presence and absence of $5 \mathrm{mmol} / \mathrm{l}$ lactisole, and insulin in the medium was measured. Values are the mean \pm S.E.M. for four experiments. $* P<0.05$ vs without lactisole. (B) MIN6 cells were preincubated for $30 \mathrm{~min}$ in $\mathrm{KRH}$ buffer containing $5.5 \mathrm{mM}$ glucose and $100 \mu \mathrm{mol} / /$ diazoxide to block the $\mathrm{K}_{\text {ATP }}$ channel. Cells were then incubated for $30 \mathrm{~min}$ in $\mathrm{KRH}$ buffer containing $30 \mathrm{mmol} / \mathrm{l} \mathrm{KCl}$ and either 5.5 or $25 \mathrm{mmol} / \mathrm{l}$ glucose in the presence and absence of $5 \mathrm{mmol} / \mathrm{l}$ lactisole. Diazoxide $(100 \mu \mathrm{mol} / \mathrm{l})$ was included in the buffer. Values are the mean \pm S.E.M. for four experiments. $\star P<0.01$ vs without lactisole.

Published by Bioscientifica Ltd 

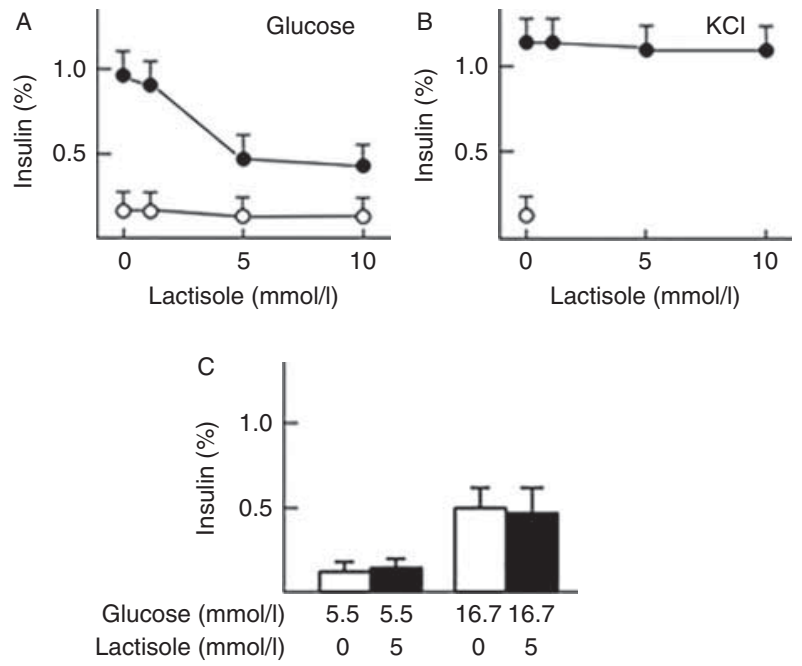

\section{Figure 8}

Effect of lactisole on insulin secretion in pancreatic islets. (A) Five islets per tube were incubated for $1 \mathrm{~h}$ with $16.7 \mathrm{mmol} / \mathrm{l}$ (filled circle) or $5.5 \mathrm{mmol} / \mathrm{l}$ glucose (open circle) in the presence of various concentrations of lactisole and insulin in the medium was measured. Values are the mean \pm s.E.M. for four experiments. (B) Five islets per tube were incubated with $40 \mathrm{mmol} / \mathrm{l}$ (filled circle) or $4.8 \mathrm{mmol} / \mathrm{K} \mathrm{KCl}$ (open circle) for $1 \mathrm{~h}$ in the presence of various concentrations of lactisole. Values are the mean \pm s.E.M. for four experiments. (C) Islets were obtained from T1R3 knockout mice. Five islets per tube were incubated with 5.5 or $16.7 \mathrm{mmol} / \mathrm{l}$ glucose in the presence and absence of $5 \mathrm{mmol} / \mathrm{l}$ lactisole and insulin secretion was measured. Values are the mean \pm s.E.M. for four experiments.

together, mT1R3 is not totally insensitive to lactisole, but when compared to hT1R3, it is less sensitive to lactisole. If one applies a slightly higher concentration of lactisole, for example $5 \mathrm{mmol} / \mathrm{l}$, it significantly inhibits mT1R3 signaling. As shown in Fig. 8C, lactisole did not affect insulin secretion in islets obtained from T1R3-null mice. This result suggests that lactisole does not have non-specific toxic effect in this condition.

Previously, we showed that gurmarin, an inhibitor of the sweet taste receptor (Shigemura et al. 2008), attenuated elevation of $\left[\mathrm{Ca}^{2+}\right]_{\mathrm{c}}$ induced by sucralose in MIN6 cells (Nakagawa et al. 2009). The results indicate that gurmarin acts as an inhibitor of the glucose-sensing receptor expressed in pancreatic $\beta$-cells. It should be noted that gurmarin does not inhibit all of the actions of sweet taste receptor agonists in $\beta$-cells. For example, gurmarin inhibits the effect of sucralose but effects of acesulfame- $K$ and glycyrrhizin are totally insensitive to gurmarin (Nakagawa et al. 2013). Since sucralose and acesulfame-K bind to a similar portion of the Venus flytrap of the sweet taste receptor (Masuda et al. 2012), the mechanism underlying the preferential effects of gurmarin (Nakagawa et al. 2013) is not clear at present. Another unique aspect of gurmarin is that it only inhibits $\left[\mathrm{Ca}^{2+}\right]_{\mathrm{c}}$ response induced by sucralose and elevation of $[\mathrm{cAMP}]_{\mathrm{c}}$ is not affected (Nakagawa et al. 2013). In this regard, gurmarin acts as a biased antagonist for T1R3 in many respects and attenuates a limited signaling cascade evoked by a limited number of agonists. As reported previously (Nakagawa et al. 2013), the glucose-sensing receptor is quite unique in the sense that various types of agonists generate distinct patterns of intracellular signals. Many sweet compounds act as biased agonists and induce diverse patterns of intracellular responses (Nakagawa et al. 2013, Kojima et al. 2014, Ohtsu et al. 2014).

In contrast to gurmarin, lactisole inhibited the effects of sucralose, acesulfame- $\mathrm{K}$, glycyrrhizin and glucose on insulin secretion, indicating that lactisole is able to block the effect of acesulfame-K, glycyrrhizin and glucose as well. With regard to intracellular messengers, lactisole inhibited the $\left[\mathrm{Ca}^{2+}\right]_{\mathrm{c}}$ response to acesulfame- $\mathrm{K}$ and sucralose but not the $[\mathrm{CAMP}]_{\mathrm{c}}$ responses to the sweeteners. Again, the inhibitory actions of lactisole are biased in some sense. Our previous study (Nakagawa et al. 2013) showed that sucralose increased $[\mathrm{cAMP}]_{\mathrm{C}}$ by a $\mathrm{G}_{\mathrm{s}}$-dependent mechanism whereas acesulfame-K-induced elevation of cAMP was also dependent on $\mathrm{Ca}^{2+}$. Presumably, lactisole is ineffective to inhibit the $\mathrm{G}_{\mathrm{s}}$-dependent pathway.

Kyriazis et al. (2014) recently postulated that the sweet taste receptor expressed in $\beta$-cells inhibits basal secretion of insulin. Their proposal is based on the observation obtained in human islets using lactisole. They showed that lactisole increased insulin secretion in the presence of 3.0 or $5.5 \mathrm{mmol} / \mathrm{l}$ glucose in human islets. In that study, they also assessed basal insulin secretion in T1R2 knockout islets. They showed that insulin secretion in the presence of 3.0 or $5.5 \mathrm{mmol} / \mathrm{l}$ glucose was not altered in T1R2-null islets (Kyriazis et al. 2012, 2014). These results are apparently inconsistent with their proposal. Because our present results also show that lactisole did not affect basal secretion in mouse $\beta$-cells, results obtained in human islets using lactisole may have provided inconsistency. At present, the reason why they observed stimulation of insulin secretion by lactisole is not clear. As mentioned in the 'Materials and methods' section, lactisole solution is acidic. If they did not adjust $\mathrm{pH}$ of the KRH buffer containing lactisole, $\mathrm{pH}$ of the buffer may have been lower than should be. Because $\beta$-cells express the proton receptor (Nakakura et al. 2012), low pH might have stimulated insulin secretion independent of the action of lactisole. Further studies are necessary to address these points.

In the present study, we stably transfected mT1R3 in HEK293 cells and observed that mT1R3 responded to

Published by Bioscientifica Ltd 
sucralose. The results clearly indicate that mT1R3 alone functions as the sweet taste-sensing receptor. Presumably, a homodimer of mT1R3 functions as a signaling receptor. It should be mentioned that we did not transfect gustducin or a chimeric $G$ protein simultaneously. This suggests that a homodimer of mT1R3 may couple to endogenous $G$ proteins expressed in HEK cells, presumably $G$ proteins of the $G_{q}$ family. The present results differ from those that previously reported that a chimeric $G$ protein was required to observe the effect of ectopically expressed T1Rs (Nelson et al. 2001). An exact reason for this discrepancy is not clear at present. The efficiency of transfection or sensitivity of the detection of changes in $\left[\mathrm{Ca}^{2+}\right]_{\mathrm{c}}$ may be possible reasons.

We showed recently that sucralose increased $[\text { ATP }]_{C}$ in MIN6 cells (Nakagawa et al. 2014). The effect of sucralose is observed even in the absence of ambient glucose. Sucralose is an artificial sweetener and is not metabolized in $\beta$-cells. We interpret these results that sucralose, by activating the glucose-sensing receptor T1R3, facilitates metabolism in $\beta$-cells and increased $[\mathrm{ATP}]_{\mathrm{c}}$. Since sucralose is capable of elevating $[\mathrm{ATP}]_{\mathrm{c}}$ in the absence of glucose, sucralose perhaps mobilizes substrate(s) from a source(s) outside the glycolytic pathway and generates ATP (Kojima et al. 2015). In addition, sucralose enhances the elevation of $[\mathrm{ATP}]_{\mathrm{C}}$ induced by methylsuccinate. This suggests that metabolism in mitochondria may also be activated by the glucose-sensing receptor T1R3 (Kojima et al. 2015).

The present results show that lactisole inhibited the action of glucose on the glucose-sensing receptor. Thus, lactisole attenuated glucose-induced increases in [NADH] and $[\mathrm{ATP}]_{\mathrm{c}}$. These results are consistent with the notion that lactisole inhibits the glucose-sensing receptor and thereby attenuated the facilitation of the glucose metabolism (Medina et al. 2014, Nakagawa et al. 2014). More importantly, lactisole inhibited insulin secretion induced by glucose. As shown in Fig. 6C, lactisole attenuated the elevation of $[\mathrm{ATP}]_{\mathrm{c}}$ induced by glucose. In addition, lactisole also reduced elevation of $\left[\mathrm{Ca}^{2+}\right]_{\mathrm{C}}$ induced by glucose. Given that glucose increases $\left[\mathrm{Ca}^{2+}\right]_{\mathrm{c}}$ by inhibiting the $\mathrm{K}_{\mathrm{ATP}}$ channel and causing $\mathrm{Ca}^{2+}$ entry via the voltage-dependent $\mathrm{Ca}^{2+}$ channel, the $\mathrm{K}_{\text {ATP }}$ channel dependent pathway is inhibited partially by lactisole. As shown in Fig. 7B, lactisole inhibited insulin secretion induced by glucose in the presence of diazoxide and high concentration of $\mathrm{KCl}$. Hence, the $\mathrm{K}_{\mathrm{ATP}}$ channel independent pathway or the amplifying pathway is also inhibited partially by lactisole. These results are consistent with the report by Aizawa et al. (1994). Collectively, the glucose-sensing receptor is involved in both $\mathrm{K}_{\mathrm{ATP}}$ channel-dependent and independent pathways. This is not surprising because the glucose-sensing receptor modulates glucose metabolism and promotes ATP generation (Kojima et al. 2015).

Lactisole is commercially available and may be useful to assess the function and physiological role of the glucose-sensing receptor T1R3 expressed in $\beta$-cells. Again, we should keep in mind that lactisole inhibits the calcium signaling system activated by the glucose-sensing receptor, but activation of the cAMP pathway is not affected by the compound. We may underestimate the role of the glucose-sensing receptor. In any event, further studies are necessary to elucidate the role of the glucosesensing receptor in the action of glucose in $\beta$-cells.

\section{Declaration of interest}

The authors declare that there is no conflict of interest that could be perceived as prejudicing the impartiality of the research reported.

\section{Funding}

This work was supported by a Grant-in-Aid for Scientific Research from the Ministry of Education, Science, Sports and Culture of Japan.

\section{Acknowledgements}

The authors were grateful to Mayumi Odagiri for her secretary assistance during the preparation of the manuscript.

\section{References}

Aizawa T, Sato Y, Ishihara F, Taguchi N, Komatsu M, Suzuki N, Hashizume K \& Yamada T 1994 ATP-sensitive $\mathrm{K}^{+}$channel-independent glucose action in rat pancreatic $\beta$-cell. American Journal of Physiology 266 C622-C627.

Ashcroft FM \& Rorsman P 1989 Electrophysiology of the pancreatic $\beta$-cell. Progress in Biophysics and Molecular Biology 54 87-143. (doi:10.1016/ 0079-6107(89)90013-8)

Bezencon C, le Coutre J \& Damak S 2007 Taste-signaling proteins are coexpressed in solitary intestinal epithelial cells. Chemical Senses $\mathbf{3 2}$ 41-49. (doi:10.1093/chemse/bj1034)

Gembal M, Gilon P \& Henquin JC 1992 Evidence that glucose can control insulin release independently from its action on ATP-sensitive $\mathrm{K}^{+}$ channels in mouse B cells. Journal of Clinical Investigation 89 1288-1295. (doi:10.1172/JCI115714)

Geraedts MC, Takahashi T, Vigues S, Markwardt MC, Nkobena A, Cockerham RE, Hajnal A, Dotson CD, Rizzo MA \& Munger SD 2012 Transformation of postingestive glucose responses after deletion of sweet taste receptor subunits or gastric bypass surgery. American Journal of Physiology 303 E464-E474. (doi:10.1152/ajpendo.00163.2012)

Gotoh M, Maki T, Koizumi T, Satomi S \& Monaco AP 1985 An improved method for isolation of mouse pancreatic islets. Transplantation 40 437-438. (doi:10.1097/00007890-198510000-00018)

Henquin JC 2009 Regulation of insulin secretion: a matter of phase control and amplitude modulation. Diabetologia 52 738-751. (doi:10.1007/ s00125-009-1314-y)

Published by Bioscientifica Lto http://joe.endocrinology-journals.org DOI: $10.1530 / \mathrm{JOE}-15-0102$
(C) 2015 The authors Printed in Great Britain 
Jang HJ, Kokrashvili Z, Theodorakis MJ, Carloson OD \& Kim BJ 2010 Gut-expressed gustducin and taste receptors regulate secretion of glucagon-like peptide-1. PNAS 104 15069-15074. (doi:10.1073/pnas. 0706890104)

Jiang P, Cui M, Zhao B, Liu Z, Snyder LA, Bernard LM, Osman R, Margolskee RF \& Max M 2005 Lactisole interacts with the transmembrane domains of human T1R3 to inhibit sweet taste. Journal of Biological Chemistry $\mathbf{2 8 0}$ 15238-15246. (doi:10.1074/jbc.M414287200)

Johnson C, Birch GG \& MacDougall DB 1994 The effect of the sweetness inhibitor 2(-4-methoxyphenoxy)propanoic acid (sodium salt) (Na-PMP) on the taste of bitter-sweet stimuli. Chemical Senses 19 349-358. (doi:10.1093/chemse/19.4.349)

Kojima I, Nakagawa Y, Ohtsu Y, Medina A \& Nagasawa M 2014 Sweet tastesensing receptors expressed in pancreatic $\beta$-cells: sweet molecules act as biased agonists. Endocrinology and Metabolism 29 1-8. (doi:10.3803/ EnM.2014.29.1.12)

Kojima I, Nakagawa Y, Ohtsu Y, Hamano K, Medina J \& Nagasawa M 2015 Return of the glucoreceptor: glucose activates the glucose-sensing receptor T1R3 and facilitates metabolism in pancreatic $\beta$-cells. Journal of Diabetes Investigation 6 256-263. (doi:10.1111/jdi.12304)

Kyriazis GA, Soundarapandian MM \& Tyberg B 2012 Sweet taste receptor signaling in $\beta$ cells mediates fructose-induced potentiation of glucosestimulated insulin secretion. PNAS 109 E524-E532. (doi:10.1073/pnas. 1115183109)

Kyriazis GA, Smith KR, Tyrberg B, Hussain T \& Pratley RE 2014 Sweet taste receptor regulate basal secretion and contribute to compensatory insulin hypersecretion during the development of diabetes in male mice. Endocrinology 155 2112-2121. (doi:10.1210/en. 2013-2015)

Malaisse WJ 2014 Insulin release: the receptor hypothesis. Diabetologia $\mathbf{5 7}$ 1287-1290. (doi:10.1007/s00125-014-3221-0)

Margolskee RF, Dyer J, Kokrashvili Z, Salmon KS, Ilegems E, Daly K, Maillet EL, Ninomiya Y, Mosinger B \& Shirazi-Beechy SP 2007 T1R3 and gustducin in gut sense: sugars to regulate expression of $\mathrm{Na}^{+}$-glucose cotransporter 1. PNAS 104 15075-15080. (doi:10.1073/pnas. 0706678104)

Masubuchi Y, Nakagawa Y, Ma JH, Sasaki T, Kitamuta T, Yamamoto Y, Kurose H, Kojima I \& Shibata H 2013 A novel regulatory function of sweet taste-sensing receptor in adipogenic differentiation of 3T3-L1 cells. PLOS ONE 8 e54500. (doi:10.1371/journal.pone. 0054500)

Masuda K, Koizumi A, Nakajima K, Tanaka T, Abe K, Misaka T \& Ishiguro M 2012 Characterization of the modes of binding between human sweet taste receptor and low-molecular-weight sweet compounds. PLoS ONE 7 e35380. (doi:10.1371/journal.pone.0035380)

Medina A, Nakagawa Y, Ma J, Li L, Hamano K, Akimoto T, Ninomiya Y \& Kojima I 2014 Expression of the glucose-sensing receptor T1R3 in pancreatic islet. Endocrine Journal 61 797-805. (doi:10.1507/endocrj. EJ14-0221)

Miyazaki J, Araki K, Yamamoto E, Ikegami H, Asano T, Oka Y \& Yamamura Y 1990 Establishment of a pancreatic $\beta$-cell line that retains glucose-inducible insulin secretion. Endocrinology 127 126-132. (doi:10.1210/endo-127-1-126)

Nakagawa Y, Nagasawa M, Yamada S, Hara A, Mogami H, Nicolaev VO, Lohse MJ, Shigemura N, Ninomiya Y \& Kojima I 2009 Sweet taste receptor expressed in pancreatic $\beta$-cells activates the calcium and cyclic AMP signaling system and stimulates insulin secretion. PLOS ONE 4 e5106. (doi:10.1371/journal.pone.0005106)

Nakagawa Y, Nagasawa M, Mogami H, Lohse MJ, Ninomiya Y \& Kojima I 2013 Multimodal function of the sweet taste receptor expressed in pancreatic $\beta$-cells: generation of diverse patterns of intracellular signals by sweet agonists. Endocrine Journal 60 1191-1206. (doi:10.1507/ endocrj.EJ13-0282)

Nakagawa Y, Ohtsu Y, Nagasawa M, Shibata H \& Kojima I 2014 Glucose promotes its own metabolism by acting on the cell-surface glucosesensing receptor T1R3. Endocrine Journal 61 119-131. (doi:10.1507/ endocrj.EJ13-0431)

Nakakura T, Mogi C, Tobo M, Tomura H, Sato K, Kobayashi M, Ohnishi H, Tanaka S, Wayama M, Sugiyama T et al. 2012 Deficiency of protonsensing ovarian cancer $G$ protein-coupled receptor 1 attenuates glucose-stimulated insulin secretion. Endocrinology 153 4171-4180. (doi:10.1210/en.2012-1164)

Nelson G, Hoon MA, Chandrasekar J, Zhang Y, Ryba NJ \& Zuker CS 2001 Mammalian sweet taste receptor. Cell 106 381-390. (doi:10.1016/ S0092-8674(01)00451-2)

Newsholme P, Cruzat V, Arfuso F \& Keane K 2014 Nutrient regulation of insulin secretion. Journal of Endocrinology 221 R105-R120. (doi:10.1530/JOE-13-0616)

Nikolaev VO, Bunemann M, Hein L, Hannawacker A \& Lohse MJ 2004 Novel signal chain cAMP sensors for receptor-mediated signal propagation. Journal of Biological Chemistry 279 37215-37218. (doi:10.1074/jbc.C400302200)

Ohtsu Y, Nakagawa Y, Nagasawa M, Takeda S, Arakawa H \& Kojima I 2014 Diverse signaling system activated by the sweet taste-sensing receptor in human GLP-1-secreting cells. Molecular and Cellular Endocrinology 394 70-79. (doi:10.1016/j.mce.2014.07.004)

Oya M, Suzuki H, Watanabe Y, Sato M \& Tsuboi T 2011 Amino acid taste receptor regulates insulin secretion in pancreatic $\beta$-cell line MIN6 cells. Genes to Cells 16 608-616. (doi:10.1111/j.1365-2443.2011. 01509.x)

Rasmussen H, Zawalich KC, Ganesan S, Calle R \& Zawalich WS 1990 Physiology and pathophysiology of insulin secretion. Diabetes Care $\mathbf{1 3}$ 655-666. (doi:10.2337/diacare.13.6.655)

Roper SD 2007 Signal transduction and information processing in mammalian taste buds. Pflügers Archiv: European Journal of Physiology 454 759-776. (doi:10.1007/s00424-007-0247-x)

Roper SD 2013 Taste buds as peripheral chemosensory processors. Seminars in Cell \& Developmental Biology 24 71-79. (doi:10.1016/j.semcdb.2012. 12.002)

Rorsman P 1997 The pancreatic $\beta$-cell as a fuel sensor: an electrophysiologist's viewpoint. Diabetologia 40 487-495. (doi:10.1007/ s001250050706)

Sato Y, Aizawa T, Komatsu M, Okada N \& Yamada T 1992 Dual functional role of membrane depolarization/ $\mathrm{Ca}^{2+}$ influx in ray pancreatic B cell. Diabetes 41 438-443. (doi:10.2337/diab.41.4.438)

Sclafani A \& Perez C 1997 Cypha [propionic acid, 2-(4-methoxyphenol) salt] inhibits sweet taste in humans, but not in rats. Physiology \& Behavior 61 25-29. (doi:10.1016/S0031-9384(96)00316-2)

Shigemura N, Nakao K, Yasuo T, Murata Y, Yasumatsu K \& Ninomiya Y 2008 Gurmarin sensitivity of sweet taste response is associated with co-expression patterns of T1r2, T1r3 and gustducin. Biochemical and Biophysical Research Communications 367 356-363. (doi:10.1016/j.bbrc. 2007.12.146)

Temussi P 2007 The sweet taste receptor: a single receptor with multiple sites and modes of interaction. Advances in Food and Nutrition Research 53 199-239. (doi:10.1016/S1043-4526(07)53006-8)

Xu H, Staszewski L, Tang H, Adler E, Zoller M \& Li X 2004 Different functional roles of T1R subunits in the heteromeric taste receptors. PNAS 101 14258-14263. (doi:10.1073/pnas. 0404384101)

Received in final form 18 May 2015

Accepted 20 May 2015

Accepted Preprint published online 20 May 2015 http://joe.endocrinology-journals.org

DOI: $10.1530 / J O E-15-0102$ (c) 2015 The authors Printed in Great Britain
Published by Bioscientifica Ltd 